\title{
FOUR-YEAR FIELD EXPERIMENT ON NITROGEN APPLICATION TO SUNFLOWER GENOTYPES GROWN IN SEMIARID CONDITIONS
}

\author{
De Giorgio, D. ${ }^{*}$, Montemurro, F. and Fornaro, F.
}

C.R.A. - Istituto Sperimentale Agronomico, Via C. Ulpiani, 5, Bari 70125, Italy

Received: July 10, 2006 Accepted: September 15, 2007

SUMMARY

A four-year field experiment was carried out to study the effects of different $\mathrm{N}$ levels on yield, yield components, $\mathrm{N}$ uptake and seed quality of sunflower genotypes grown in semiarid Mediterranean conditions. Five genotypes (four commercial hybrids and one newly selected genotype) and three $\mathrm{N}$ fertilization levels $\left(0,50\right.$ and $\left.100 \mathrm{~kg} \mathrm{~N} \mathrm{ha}^{-1}\right)$ were compared over four years $(1996,1997$, 1998 and 1999).

Sunflower plants were taken at flowering time and their dry weight, leaf area index and total $\mathrm{N}$ content were determined. At maturity stage, yield, yield components, oil content, protein content, $\mathrm{N}$ uptake and seed quality were determined.

The obtained results indicated significant differences in yield performance (seed, oil and protein production) throughout the years (from $2.52 \mathrm{t} \mathrm{ha}^{-1}$ in 1996 to 3.81 in 1999), confirming the need to use recommended genotypes and adjust fertilizer rates to crops requirements, especially in the Mediterranean environment where weather conditions are unpredictable and inconsistent. In fact, the genotypes showed different behavior in all years regarding total $\mathrm{N}$ uptake, seed, oil and protein production, indicating that the sunflower crop is responsive to agronomic management. The highest level of $\mathrm{N}$ fertilizer resulted in the best sunflower performance although, due to variations in year and genotype, fertilizer $\mathrm{N}$ could be applied according to total annual $\mathrm{N}$ uptake. Finally, the $\mathrm{N}$ uptake and the diameter of head were the most important parameters that influenced sunflower yield performance.

Key words: nitrogen fertilization, $\mathbf{N}$ uptake, seed quality, sunflower, yield components

\section{INTRODUCTION}

Sunflower (Helianthus annuus L.) is one of the most important oil crops and, due to favorable agricultural policies, its acreage has been expanding in recent

* Corresponding author: Phone: +39 080 5475015; Fax: +39080 5475023; e-mail: donato.degiorgio@tin.it 
years, also in Mediterranean countries because of its importance in many dryland farming systems (Lòpez-Bellido et al., 2003). In this area, selection of genotypes with high performance and good adaptation to the specific environmental conditions could be an important goal, especially when low input is adopted (Leto et al., 1997). In fact, in semi arid climates characterized by high variability of rainfall distribution, the main factors limiting growth and production are water and nitrogen (N) supplies. Therefore, a particular amount of $\mathrm{N}$ fertilizer added to a sunflower crop could result in a depletion or accumulation of soil mineral $\mathrm{N}$, depending on rainfall, plant growth and genotype utilized.

Effects of $\mathrm{N}$ fertilization on sunflower yield and quality have come under scientific scrutiny (Hocking and Steer, 1995; Thavaprakash et al., 2002), because $\mathrm{N}$ is a major nutrient for plants and it increases total biomass production, yield and its components. Furthermore, under Mediterranean conditions, $\mathrm{N}$ fertilization increases total $\mathrm{N}$ uptake in several crops (Delogu et al., 1998; Montemurro et al., 2002) and in sunflowers in other environments (Steer et al., 1985; Hocking and Steer, 1995) and, due to high correlations with yield, also crop performance. Conversely, inaccurate distribution of $\mathrm{N}$ fertilizer induces $\mathrm{N}$ dissipation in the environment due to high $\mathrm{N}$ mobility in the soil (Magdoff et al., 1997; Janzen et al., 2003), therefore, the choice of an $\mathrm{N}$-efficient cropping system (genotype and rotation) and an adequate level of $\mathrm{N}$ fertilizer require methods and knowledge to evaluate $\mathrm{N}$ effects on plant yield and its environmental risks. Consequently, appropriate genotypes and $\mathrm{N}$ fertilization levels are important features for farmers, especially in Mediterranean conditions where dry growing seasons and water deficit in the soil influence yield, growth and plant development (Botella Miralles et al., 1997; Corbeels et al., 1998). The aim of this work was to study the behavior of different sunflower hybrids cropped under different $\mathrm{N}$ levels in Mediterranean conditions. The evaluation of yield reduction and its interaction with different genotypes, quality performance and yield components under $\mathrm{N}$ constraints were further investigated.

\section{MATERIALS AND METHODS}

This research was carried out at Istituto Sperimentale Agronomico, the experimental farm in Foggia (Southern Italy), an area with a typical Mediterranean environment ("accentuated thermo Mediterranean" as classified by UNESCO-FAO). It is characterized by temperatures that can range below $0^{\circ} \mathrm{C}$ in winter and up to $40^{\circ} \mathrm{C}$ in summer, with uneven rainfall distribution during the year, the precipitation occurring mainly in the winter season. The soil, typical of the flat land of Apulia Tavoliere (South Italy), has a clay-loamy texture and is classified by Soil Taxonomy-USDA as a fine, mesic, Typic Chromoxerert. Its main characteristics are as follows: total $\mathrm{N}=1.34 \mathrm{~g} \mathrm{~kg}^{-1}$; available $\mathrm{P}=27 \mathrm{mg} \mathrm{kg}^{-1}$; exchangeable $\mathrm{K}=1018 \mathrm{mg} \mathrm{kg}^{-1}$; organic matter $=20.7 \mathrm{~g} \mathrm{~kg}^{-1}$; $\mathrm{pH}=8.83$. 
The research was conducted during 4 years (1996, 1997, 1998 and 1999) on four sunflower hybrids (Isoleic, Sanbro, Akiles, Select) and one new genotype (Prointa AGD) selected by INTA (Argentina). Three $\mathrm{N}$ fertilization levels $(0,50$ and $100 \mathrm{~kg} \mathrm{~N} \mathrm{ha}^{-1}$, indicated as NO, N50 and N100, respectively) were also compared in this research. Prointa AGD was included in the trials from 1997. The experimental design was a split-plot with three replications; the main plot was assigned to the nitrogen level and the sub plot to the genotype. The elementary plot consisted of 45 $\mathrm{m}^{2}$ with about 7 plant $\mathrm{m}^{-2}$. The $\mathrm{N}$ fertilizer, as ammonium nitrate, was distributed in two equal amounts during sunflower growth (at 3-4 and 11-12 leaves) for N50 (25 $\mathrm{kg} \mathrm{ha}^{-1}$ in each distribution) and N100 (50 kg ha-1). Irrigation was performed only once during the sunflower cycle, at the early flowering stage $(80 \mathrm{~mm})$.

At flowering time, $1 \mathrm{~m}^{2}$ of sunflower plants were taken and leaf area index (LAI), dry weight and total $\mathrm{N}$ content from different parts of the plant were determined by a CHN elemental analyzer (Fison EA 1108). The last two parameters allowed the calculation of $\mathrm{N}$ uptake ( $\mathrm{N}$ content per dry weight). At maturity, a sample of $10 \mathrm{~m}^{2}$ was collected from each plot and the following parameters were determined: seed yield (at 10\% moisture level), yield components (plant height, diameter of the fertile and infertile head), seed quality (1000-seed weight, hectoliter weight, ash and crude fiber), seed and stem $\mathrm{N}$ uptake, protein content and oil content (extraction with diethyl ether in Soxhlet for $36 \mathrm{~h}$ ). To better understand the yield performance of the treatments, oil production (oil yield), protein production (protein yield) and harvest index (ratio of seed yield and total plant biomass at harvest) were also calculated.

Statistical analyses were made using the SAS software package (SAS Institute, 1990), considering years as random and genotype and $\mathrm{N}$ fertilization levels as fixed effects. Differences among treatments were evaluated using Duncan's range multiple test (DMRT), whereas Pearson correlation coefficients were used to compare yield performance with yield components, seed quality and $\mathrm{N}$ uptake.

\section{RESULTS AND DISCUSSION}

Figure 1 shows the long-term (45 years) mean, annual and seasonal rainfalls during the four-year field experiment in Foggia. No large difference was found among the years in respect to the long-term mean total rainfall, but marked variations were recorded in spring and summer, which are most important periods for sunflower growth. In particular, the sums of rainfall in these two seasons were 282, 156, 245, 254 and 226 for 1996, 1997, 1998, 1999 and the long-term period, respectively. Therefore, although the sunflower plants received a single irrigation during early flowering time (about $80 \mathrm{~mm}$ ), 1997 presented a greater lack of rainfall during the cropping cycle $(70 \mathrm{~mm}$ and about $100 \mathrm{~mm}$, in respect to the long-term period and other experimental years, respectively), which can strongly influence the sunflower response to fertilizers. In fact, Lòpez-Bellido et al. (2003) reported that sunflower $\mathrm{N}$ uptake, and consequently its yield performance, are likely to increase if there is adequate soil water. No substantial difference in mean temperature was 
found either in spring $\left(17.8,17.3,19.1,19.5\right.$ and $17.3^{\circ} \mathrm{C}$ for $1996,1997,1998$, 1999 and the long-term period, respectively) or summer $\left(22.6,24.2,25.7,24.7^{\circ} \mathrm{C}\right.$ and $23.7^{\circ} \mathrm{C}$ ) through the experimental years.

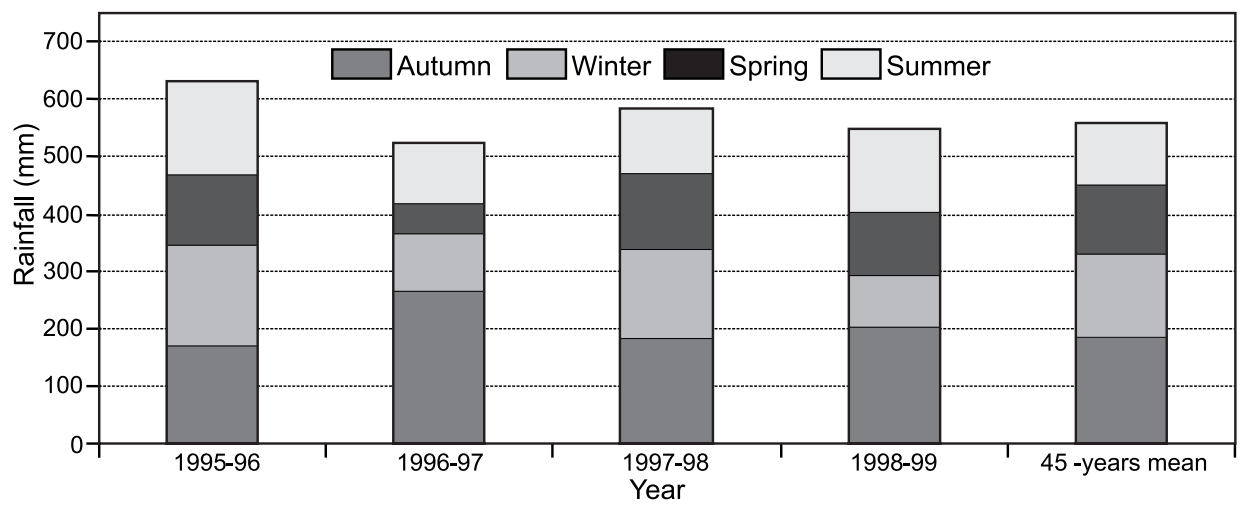

Figure 1: Long-term (45 years) mean, annual and seasonal rainfalls during the field experiment period in Foggia

Significant differences in seed yield were found for years, genotypes, $\mathrm{N}$ fertilization levels, year $\mathrm{x}$ genotype and years $\mathrm{x} \mathrm{N}$ fertilization level interactions. The interaction genotype $\times \mathrm{N}$ fertilization showed no significant difference, which indicated that the genotypes responded similarly to $\mathrm{N}$ increase regarding their yield performance (Table 1). The variation of climatic conditions significantly influenced yield, yield components, quality and $\mathrm{N}$ uptake, but not the oil content, while significant differences were found among the genotype and the interaction year $\times$ genotypes in all parameters considered. The level of $\mathrm{N}$ fertilization influenced yields (seed, oil and protein production) and $\mathrm{N}$ uptake, but not seed quality (oil percentage and protein content). Significant differences in $\mathrm{N}$ uptake (seed and total) were found for year, genotype, $\mathrm{N}$ fertilization level and year $\times \mathrm{N}$ level interaction (Table 1). Also for these parameters, year $\times \mathrm{N}$ level and genotype $\times \mathrm{N}$ level were insignificant, indicating that the genotypes responded similarly to an increase in $\mathrm{N}$.

Table 1: Significance of $\mathrm{F}$ values from the analysis of variance for the main parameters measured

\begin{tabular}{|c|c|c|c|c|c|c|c|c|c|c|c|}
\hline & d.f. & Yield & $=\frac{\stackrel{\vec{c}}{0}}{\overline{0}}$ & 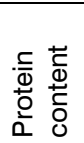 & $\overline{\overline{0}} \frac{\frac{0}{0}}{\frac{0}{\lambda}}$ & $\begin{array}{l}\frac{5}{\bar{D}} \\
\frac{0}{0} \\
\frac{0}{0} \\
\frac{0}{2}\end{array}$ & 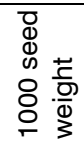 & 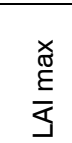 & 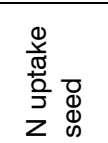 & 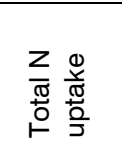 & $\mathrm{HI}$ \\
\hline & & $\left(\mathrm{t} \mathrm{ha}^{-1}\right)$ & (\%) & (\%) & $\left(\mathrm{t} \mathrm{ha}^{-1}\right)$ & $\left(\mathrm{t} \mathrm{ha}^{-1}\right)$ & (g) & & $\left(\mathrm{kg} \mathrm{ha}^{-1}\right)$ & $\left(\mathrm{kg} \mathrm{ha}^{-1}\right)$ & $(\%)$ \\
\hline Year $(Y)$ & 3 & 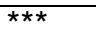 & n.s & 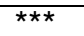 & 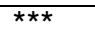 & $\star \star \star \star$ & 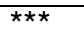 & $\star \star \star$ & $\star \star \star$ & 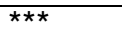 & 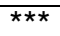 \\
\hline Genotype (G) & 4 & $\star \star \star \star ~$ & * & 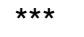 & 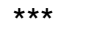 & *** & $\star \star \star *$ & $\star * *$ & 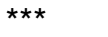 & ** & 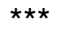 \\
\hline $\mathrm{N}$ level $(\mathrm{N})$ & 2 & ** & n.s. & n.s. & ** & * & n.s. & ** & * & *** & n.s. \\
\hline$Y \times G$ & 12 & $\star \star \star \star$ & $\star \star \star *$ & 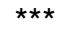 & 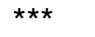 & *** & $\star \star \star *$ & ** & *** & $\star \star \star \star ~$ & 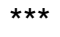 \\
\hline $\mathrm{Y} \times \mathrm{N}$ & 6 & * & n.s. & n.s. & n.s. & n.s. & n.s. & n.s. & n.s. & n.s. & n.s. \\
\hline $\mathrm{G} \times \mathrm{N}$ & 8 & n.s & n.s. & n.s. & n.s. & n.s. & n.s. & n.s. & n.s. & n.s. & n.s. \\
\hline $\mathrm{Y} \times \mathrm{G} \times \mathrm{N}$ & 24 & n.s. & n.s. & * & n.s. & n.s & n.s. & n.s. & n.s. & n.s. & n.s. \\
\hline
\end{tabular}


Table 2 shows the genotype and year interactions for seed yield. Significant differences were found among the years $\left(3.05,2.52,3.47\right.$ and $3.81 \mathrm{t} \mathrm{ha}^{-1}$ for 1996, 1997, 1998 and 1999, respectively) and the genotypes (2.89, 3.44, 3.26, 3.23 and $3.30 \mathrm{t} \mathrm{ha}^{-1}$ for Isoleic, Sanbro, Akiles, Select and Prointa AGD, respectively).

Table 2: Genotype $\times$ year interaction for seed yield $\left(\mathrm{t} \mathrm{ha}^{-1}\right)$

\begin{tabular}{lccccc}
\hline Genotype & \multicolumn{5}{c}{ Year } \\
\cline { 2 - 5 } & 1996 & 1997 & 1998 & 1999 & Mean \\
\hline Isoleic & $2.29 \mathrm{f}$ & $2.50 \mathrm{ef}$ & $3.26 \mathrm{~cd}$ & $3.50 \mathrm{bd}$ & $2.89 \mathrm{~b}$ \\
Sanbro & $3.44 \mathrm{~cd}$ & $2.42 \mathrm{ef}$ & $3.46 \mathrm{~cd}$ & $4.42 \mathrm{a}$ & $3.44 \mathrm{a}$ \\
Akiles & $3.16 \mathrm{~d}$ & $2.77 \mathrm{e}$ & $3.43 \mathrm{~cd}$ & $3.67 \mathrm{bc}$ & $3.26 \mathrm{a}$ \\
Select & $3.31 \mathrm{~cd}$ & $2.59 \mathrm{ef}$ & $3.49 \mathrm{bd}$ & $3.55 \mathrm{bd}$ & $3.23 \mathrm{a}$ \\
Prointa AGD & - & $2.30 \mathrm{f}$ & $3.69 \mathrm{bc}$ & $3.92 \mathrm{~b}$ & $3.30 \mathrm{a}$ \\
\hline Mean & $3.05 \mathrm{c}$ & $2.52 \mathrm{~d}$ & $3.47 \mathrm{~b}$ & $3.81 \mathrm{a}$ & \\
\hline
\end{tabular}

The values of the interaction, mean of year and genotype followed by different letters are significantly different according to DMRT at $\mathrm{P} \leq 0.05$

The low amount of rainfall observed in 1996 determined a lower amount of water available for grain filling, increasing the detrimental effects of water stress on the formation of achenes and, consequently, reducing grain yield, according to the results found by Botella Miralles et al. (1997). The highest seed yield was observed for Sanbro in 1999 (4.42 $\left.\mathrm{t} \mathrm{ha}^{-1}\right)$, which exhibited good performance throughout the entire trial, while the hybrid Isoleic achieved a lower yield even with favorable environmental conditions as in 1996.

Table 3: Genotype $\times \mathrm{N}$ fertilization level interaction for seed yield $\left(\mathrm{t} \mathrm{ha} \mathrm{a}^{-1}\right.$ )

\begin{tabular}{lcccc}
\hline \multirow{2}{*}{ Genotype } & \multicolumn{4}{c}{$\mathrm{N}$ fertilization } \\
\cline { 2 - 5 } & $\mathrm{N} 0$ & $\mathrm{~N} 50$ & $\mathrm{~N} 100$ & Mean \\
\hline Isoleic & $2.97 \mathrm{~cd}$ & $2.69 \mathrm{~d}$ & $3.00 \mathrm{bd}$ & $2.89 \mathrm{~b}$ \\
Sanbro & $3.31 \mathrm{ac}$ & $3.51 \mathrm{a}$ & $3.49 \mathrm{a}$ & $3.44 \mathrm{a}$ \\
Akiles & $3.17 \mathrm{ac}$ & $3.20 \mathrm{ac}$ & $3.40 \mathrm{a}$ & $3.26 \mathrm{a}$ \\
Select & $3.13 \mathrm{ac}$ & $3.14 \mathrm{ac}$ & $3.43 \mathrm{a}$ & $3.23 \mathrm{a}$ \\
Prointa AGD & $3.37 \mathrm{ab}$ & $3.12 \mathrm{ac}$ & $3.41 \mathrm{a}$ & $3.30 \mathrm{a}$ \\
\hline Mean & $3.18 \mathrm{~b}$ & $3.13 \mathrm{~b}$ & $3.34 \mathrm{a}$ & \\
\hline
\end{tabular}

The values of the interaction, mean of $\mathrm{N}$ fertilization and genotype followed by different letters are significantly different according to DMRT at $\mathrm{P} \leq 0.05$

Table 4: Year $\times \mathrm{N}$ fertilization level interaction for seed yield $\left(\mathrm{t} \mathrm{ha}^{-1}\right)$

\begin{tabular}{lcccc}
\hline \multirow{2}{*}{ Year } & \multicolumn{4}{c}{$\mathrm{N}$ fertilization } \\
\cline { 2 - 5 } & $\mathrm{N} 0$ & $\mathrm{~N} 50$ & $\mathrm{~N} 100$ & Mean \\
\hline 1996 & $2.79 \mathrm{de}$ & $2.95 \mathrm{~d}$ & $3.41 \mathrm{c}$ & $3.05 \mathrm{c}$ \\
1997 & $2.55 \mathrm{e}$ & $2.46 \mathrm{e}$ & $2.53 \mathrm{e}$ & $2.52 \mathrm{~d}$ \\
1998 & $3.44 \mathrm{c}$ & $3.42 \mathrm{c}$ & $3.54 \mathrm{bc}$ & $3.47 \mathrm{~b}$ \\
1999 & $3.86 \mathrm{ab}$ & $3.68 \mathrm{ac}$ & $3.90 \mathrm{a}$ & $3.81 \mathrm{a}$ \\
\hline Mean & $3.18 \mathrm{~b}$ & $3.13 \mathrm{~b}$ & $3.34 \mathrm{a}$ & \\
\hline
\end{tabular}

The values of the interaction, mean of $\mathrm{N}$ fertilization and year followed by different letters are significantly different according to DMRT at $\mathrm{P} \leq 0.05$ 

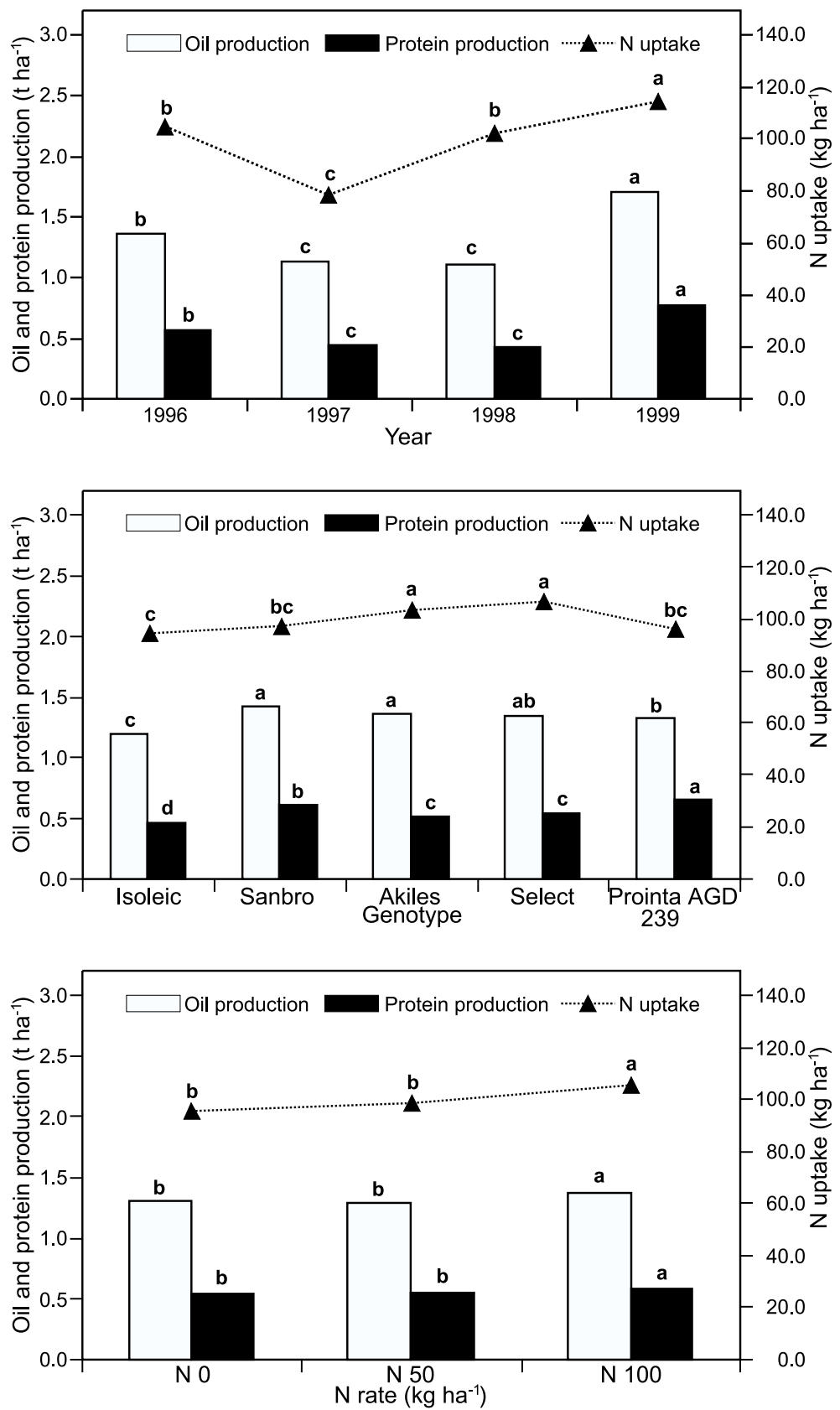

Figure 2: Sunflower total $N$ uptake, oil and protein production in the experimental treatments (Within treatments (year, genotype and $N$ fertilization) and parameters (grain yield, oil and protein production) means followed by different letters are significantly different according to DMRT at $P \leq 0.05)$. 
The high $\mathrm{N}$ application rates used by farmers are justified because they increase plant growth, but in general, $\mathrm{N}$ fertilization of sunflowers grown in semiarid climates is a controversial practice, since $\mathrm{N}$ availability is governed by rainfall pattern (Lòpez-Bellido et al., 2003). In our study, the N100 treatment had a higher seed yield than the N50 and NO treatments $\left(3.34,3.13\right.$ and $3.18 \mathrm{t} \mathrm{ha}^{-1}$, respectively) (Table 3). Furthermore, it is well known that the reduction of seed oil due to the addition of $\mathrm{N}$ is relatively small and it is compensated for by the increase of seed yield (Scheiner et al., 2002). Therefore, the results of our four-year field experiment with five genotypes indicated that the annual rate of $\mathrm{N}$ fertilizer could be around $100 \mathrm{~kg} \mathrm{ha}^{-1}$, according to the level of $\mathrm{N}$ uptake (Figure 2). Conversely, the yield of the hybrid Isoleic was significantly lower in respect to the other genotypes with all levels of $\mathrm{N}$ fertilization, confirming that yield performance of the genotypes is independent from $\mathrm{N}$ fertilizer application, as shown by no significant interaction between genotypes and $\mathrm{N}$ levels (Table 1 ).

Table 4 shows the effect of year and $\mathrm{N}$ fertilization interaction on seed yield. Significant differences were found throughout the field experiment $(3.05,2.52,3.47$ and $3.81 \mathrm{t} \mathrm{ha}^{-1}$ for 1996, 1997, 1998 and 1999, respectively), indicating that the weather conditions strongly influenced the performance of sunflowers in a Mediterranean environment (Botella Miralles et al., 1997). Furthermore, the interaction year $\times \mathrm{N}$ fertilization was significant (Table 1), and therefore, at the same $\mathrm{N}$ fertilization level (N100), the seed yield reached the highest value (3.90 $\mathrm{t} \mathrm{ha}^{-1}$ for 1999) and one of the lowest (2.53 $\mathrm{tha}^{-1}$ for 1997).

Figure 2 shows the total $\mathrm{N}$ uptake, oil and protein production in the experimental treatments. Significantly higher values of these parameters were found in 1999 compared with the other experiment years. The total $\mathrm{N}$ uptake in 1997 (78.4 kg ha${ }^{1}$ ) was extremely low confirming that this parameter is limited by drought, thus consequently affecting sunflower yield performance (Table 2). Similar results were obtained by Corbeels et al. (1998). In our study, the genotypes tested showed different behavior in total $\mathrm{N}$ uptake, oil and protein production, indicating that sunflower crops are particularly susceptible to different agronomic management (Owen, 1983; Ujjanaiah et al., 1995; Murillo et al., 1998). In particular, Prointa AGD showed the highest value of protein production ( $\left.0.66 \mathrm{t} \mathrm{ha}^{-1}\right)$, Sanbro and Akiles of oil production (1.42 and $1.36 \mathrm{t} \mathrm{ha}^{-1}$, respectively) and Akiles and Select of total $\mathrm{N}$ uptake (103.4 and $106.8 \mathrm{~kg} \mathrm{ha}^{-1}$, respectively). The highest performance in seed yield (Table 2), total $\mathrm{N}$ uptake, oil and protein production (Figure 2) was obtained with $100 \mathrm{~kg} \mathrm{ha}^{-1}$ of $\mathrm{N}$ fertilizer (N100 treatment), confirming the results of other researches (Ujjanaiah et al., 1995; Dalla Costa and Giovanardi, 1996). Therefore, considering that sunflowers can absorb a high amount of residual $\mathrm{N}$ from the soil (Leto et al., 1997) and that they produce satisfactory yield with low $\mathrm{N}$ input (Sinsawat and Steer, 1993), fertilizer N should be applied only when required, according to total annual $\mathrm{N}$ uptake. 
Table 5: Yield components of the sunflower divided by year, genotype and level of $\mathrm{N}$ fertilization

\begin{tabular}{lcccccc}
\hline \multirow{2}{*}{ Treatment } & \multicolumn{5}{c}{ Parameter } \\
\cline { 2 - 6 } & $\begin{array}{c}\text { 1000 seed } \\
\text { weight }\end{array}$ & $\begin{array}{c}\text { Hectoliter } \\
\text { weight }\end{array}$ & Plant height & $\begin{array}{c}\text { Diameter fer- } \\
\text { tile head }\end{array}$ & $\begin{array}{c}\text { Diameter in- } \\
\text { fertile head }\end{array}$ & $\begin{array}{c}\text { LAl at flower- } \\
\text { ing }\end{array}$ \\
\cline { 2 - 6 } & $(\mathrm{g})$ & $(\mathrm{g})$ & $(\mathrm{cm})$ & $(\mathrm{cm})$ & $(\mathrm{cm})$ & \\
\hline & & & Year & & & \\
1996 & $51.1 \mathrm{c}$ & $40.7 \mathrm{c}$ & $135.1 \mathrm{~b}$ & $16.7 \mathrm{~b}$ & $2.81 \mathrm{a}$ & $3.91 \mathrm{a}$ \\
1997 & $50.8 \mathrm{c}$ & $41.8 \mathrm{~b}$ & $106.9 \mathrm{c}$ & $14.7 \mathrm{~d}$ & $2.95 \mathrm{a}$ & $3.29 \mathrm{~b}$ \\
1998 & $55.0 \mathrm{a}$ & $44.6 \mathrm{a}$ & $140.9 \mathrm{a}$ & $15.9 \mathrm{c}$ & $1.47 \mathrm{~b}$ & $3.39 \mathrm{~b}$ \\
1999 & $53.6 \mathrm{~b}$ & $37.9 \mathrm{~d}$ & $142.9 \mathrm{a}$ & $17.7 \mathrm{a}$ & $1.62 \mathrm{~b}$ & $3.43 \mathrm{~b}$ \\
\hline & & & Genotype & & & \\
Isoleic & $52.2 \mathrm{~b}$ & $39.2 \mathrm{c}$ & $133.3 \mathrm{~b}$ & $15.9 \mathrm{~b}$ & $2.05 \mathrm{~b}$ & $3.83 \mathrm{a}$ \\
Sanbro & $54.1 \mathrm{a}$ & $43.6 \mathrm{a}$ & $138.4 \mathrm{a}$ & $16.9 \mathrm{a}$ & $1.83 \mathrm{~b}$ & $3.19 \mathrm{~b}$ \\
Akiles & $48.8 \mathrm{c}$ & $42.2 \mathrm{~b}$ & $120.9 \mathrm{~d}$ & $16.1 \mathrm{~b}$ & $2.56 \mathrm{a}$ & $3.22 \mathrm{~b}$ \\
Select & $54.7 \mathrm{a}$ & $39.4 \mathrm{c}$ & $125.9 \mathrm{c}$ & $16.2 \mathrm{~b}$ & $2.75 \mathrm{a}$ & $3.48 \mathrm{ab}$ \\
Prointa AGD & $54.1 \mathrm{a}$ & $42.3 \mathrm{~b}$ & $140.1 \mathrm{a}$ & $16.1 \mathrm{~b}$ & $1.54 \mathrm{c}$ & $3.77 \mathrm{a}$ \\
\hline & & & Level of N & & & \\
N0 & 52.7 & 41.7 & 130.5 & 16.2 & 2.04 & $3.25 \mathrm{~b}$ \\
N50 & 53.0 & 41.1 & 131.9 & 16.1 & 2.23 & $3.56 \mathrm{a}$ \\
N100 & 52.4 & 41.1 & 131.5 & 16.3 & 2.26 & $3.64 \mathrm{a}$ \\
\hline
\end{tabular}

Within years, genotypes and $\mathrm{N}$ fertilization levels, the values in each column followed by a different letters are significantly different according to DMRT at $\mathrm{P} \leq 0.05$

Table 5 shows the sunflower yield components. Significant differences were found for all parameters in all years and genotypes tested, whereas increased values for N50 and N100 were found only for LAI at flowering time. The diameter of fertile achenes per head was higher in $1999(17.7 \mathrm{~cm})$ and for Sanbro $(16.9 \mathrm{~cm})$. There were positive and significant correlations between the diameter of fertile achenes per head and seed yield, oil and protein production $(0.6405,0.6289$ and 0.6427 for $\mathrm{P}<0.0001$, respectively) (Table 7), indicating that this yield component is the most important parameter that influences yield performance in a Mediterranean environment, as reported by Zaffaroni and Schneiter (1991) and Botella Miralles et al. (1997). Similar behavior, but with lower absolute correlation values, was observed for 1000-seed weight (Tables 5 and 7).

Finally, Table 6 shows the seed quality and $\mathrm{N}$ uptake (seed and stem) of the sunflowers. The highest value of HI was obtained in 1997, but this parameter was not in correlation with yield performance (Table 7). The highest values of ash, seed and stem N content were obtained for N100 treatment (Table 6) and these parameters were significantly correlated with seed, oil and protein production (Table 7 ). The high and positive correlations between $\mathrm{N}$ uptake and yield performance confirm that $\mathrm{N}$ nutrition is extremely important for sunflower yield performance (Hocking and Steer, 1995; Lòpez-Bellido et al., 2003). 
Table 6: Seed quality and $\mathrm{N}$ uptake (seed and stem) of the sunflower divided by year, genotype and level of $\mathrm{N}$ fertilization

\begin{tabular}{|c|c|c|c|c|c|}
\hline \multirow{3}{*}{ Treatment } & \multicolumn{5}{|c|}{ Parameter } \\
\hline & $\mathrm{HI}$ & Ash & \multirow{2}{*}{$\begin{array}{c}\text { Crude } \\
\text { fiber }\end{array}$} & $\begin{array}{c}\text { Seed } \\
\mathrm{N} \text { uptake }\end{array}$ & $\begin{array}{c}\text { Stem } \\
\text { N uptake }\end{array}$ \\
\hline & (\%) & (\%) & & $\left(\mathrm{kg} \mathrm{ha}^{-1}\right)$ & $\left(\mathrm{kg} \mathrm{ha}^{-1}\right)$ \\
\hline \multicolumn{6}{|l|}{ Year } \\
\hline 1996 & $38.0 \mathrm{~b}$ & $2.71 \mathrm{a}$ & $15.5 c$ & $86.4 a$ & $18.4 \mathrm{c}$ \\
\hline 1997 & $44.3 a$ & $2.36 c$ & $22.0 a$ & $66.6 \mathrm{~b}$ & $11.9 d$ \\
\hline 1998 & $34.3 c$ & $2.60 \mathrm{~b}$ & $19.5 b$ & $63.3 b$ & $23.8 b$ \\
\hline 1999 & $37.9 \mathrm{~b}$ & $2.58 b$ & $15.6 c$ & $89.1 \mathrm{a}$ & $25.4 a$ \\
\hline \multicolumn{6}{|l|}{ Genotype } \\
\hline Isoleic & $35.9 c$ & $2.59 \mathrm{~b}$ & $16.4 \mathrm{c}$ & $69.9 b$ & $18.3 \mathrm{c}$ \\
\hline Sanbro & $40.3 a b$ & $2.47 \mathrm{~cd}$ & $19.1 \mathrm{ab}$ & 75.9ab & $21.2 \mathrm{~b}$ \\
\hline Akiles & $38.2 \mathrm{bc}$ & $2.44 d$ & $19.6 a$ & $78.6 a$ & $18.8 \mathrm{c}$ \\
\hline Select & $38.2 \mathrm{bc}$ & $2.73 a$ & $18.2 b$ & $82.0 a$ & $18.3 c$ \\
\hline Prointa AGD & $41.4 \mathrm{a}$ & $2.55 b c$ & $18.3 b$ & $71.9 \mathrm{~b}$ & $24.2 a$ \\
\hline \multicolumn{6}{|l|}{ Level of $\mathrm{N}$} \\
\hline NO & 39.1 & $2.50 \mathrm{~b}$ & 18.3 & $73.4 b$ & $18.1 \mathrm{c}$ \\
\hline N50 & 38.2 & $2.54 a b$ & 18.3 & 74.7ab & $19.8 b$ \\
\hline N100 & 39.6 & $2.62 a$ & 18.2 & $79.5 a$ & $21.9 a$ \\
\hline
\end{tabular}

Within years, genotypes and $\mathrm{N}$ fertilization levels, the values in each column followed by a different letters are significantly different according to DMRT at $P \leq 0.05$

Table 7: Correlation coefficients among yields (seed, oil and protein production) $\times$ yield components, seed quality and $\mathrm{N}$ uptake

\begin{tabular}{|c|c|c|c|}
\hline & $\begin{array}{l}\text { Yield } \\
\left(\mathrm{t} \mathrm{ha}^{-1}\right)\end{array}$ & $\begin{array}{c}\text { Oil yield } \\
\left(\mathrm{t} \mathrm{ha}^{-1}\right)\end{array}$ & $\begin{array}{c}\text { Protein yield } \\
\left(\mathrm{t} \mathrm{ha}^{-1}\right)\end{array}$ \\
\hline $\mathrm{HI}(\%)$ & 0.0539 n.s. & 0.0593 n.s. & 0.0346 n.s. \\
\hline Oil content (\%) & -0.0707 n.s. & -0.0005 n.s. & -0.1005 n.s. \\
\hline Protein content (\%) & 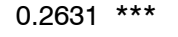 & $0.2567 \star \star \star *$ & $0.7203 * * *$ \\
\hline 1000-seed weight (g) & $0.3693 * \star \star$ & $0.3737 \star \star \star *$ & $0.3667 * * *$ \\
\hline Hectoliter weight (g) & 0.0176 n.s. & 0.0262 n.s. & -0.1213 n.s. \\
\hline Plant height (cm) & 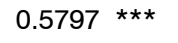 & 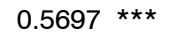 & $0.5486 * * *$ \\
\hline Diameter fertile head (cm) & $0.6405 * \star \star$ & $0.6289 * \star \star$ & 0.6427 *** \\
\hline Diameter infertile head $(\mathrm{cm})$ & $-0.4560 * * *$ & $-0.4476 * \star *$ & 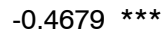 \\
\hline LAl at flowering & -0.1258 n.s. & -0.1295 n.s. & 0.0098 n.s. \\
\hline Ash (\%) & 0.1832 * & 0.1786 * & $0.2889 * * \star$ \\
\hline Crude fiber & $-0.3468 * \star *$ & $-0.3193 * \star \star$ & $-0.3116 \star \star \star *$ \\
\hline Seed $\mathrm{N}$ uptake $\left(\mathrm{kg} \mathrm{ha}^{-1}\right)$ & $0.5873 * \star \star$ & $0.5819 * \star \star$ & $0.5114^{\star * \star}$ \\
\hline Stem $\mathrm{N}$ uptake (kg ha $\left.{ }^{-1}\right)$ & $0.6171 * * *$ & $0.6146 * * *$ & $0.6096 * \star *$ \\
\hline Total $\mathrm{N}$ uptake $\left(\mathrm{kg} \mathrm{ha}^{-1}\right)$ & $0.6995 * * *$ & $0.6941 * * *$ & $0.6327 * * \star$ \\
\hline
\end{tabular}

${ }^{\star},{ }^{\star \star},{ }^{* \star *}=$ Significant at the $\mathrm{P}<0.05,0.01$ and 0.001 levels, respectively; $\mathrm{n} . \mathrm{s} .=$ not significant 


\section{CONCLUSIONS}

The results of this research indicate that weather conditions strongly influence sunflower response when different $\mathrm{N}$ fertilizer levels and genotypes are used. In fact, the year with the worst environmental conditions (1996) reached only $66.1 \%$ of the seed yield obtained in the best year (1999). The hybrids behaved differently with regard to total $\mathrm{N}$ uptake and yield production, confirming that sunflowers are responsive to different agronomic practices. The highest level of $\mathrm{N}$ fertilizer ensured better yield performance (seed, oil and protein production) in most of the tested hybrids although, for optimal financial profit, $\mathrm{N}$ fertilizer could be applied according to the calculation of crop needs for total annual $\mathrm{N}$ uptake. Therefore, in order to avoid a negative environmental impact, it is necessary to use recommended genotypes and adjust fertilizer rates to crop requirements, since excessive $\mathrm{N}$ fertilization is one of the main causes of groundwater contamination with nitrates. The $\mathrm{N}$ uptake (seed, stem and total) and head diameter (sterile and fertile) were the most important parameters that influenced the sunflower yield performance in semiarid conditions, in light of the high and positive correlations found among them.

\section{REFERENCES}

Botella Miralles, O., De Juan Valero, J.A., De Santa Olalla, M,. 1997. Growth, development and yield of five sunflower hybrids. Eur. J. of Agron. 6: 47-59.

Corbeels, M., Hofman, G., Van Cleemput, O., 1998. Residual effect of nitrogen fertilization in a wheat-sunflower cropping sequence on a vertisol under semi-arid Mediterranean conditions. Eur. J. of Agron. 9: 109-116.

Delogu, G., Cattivelli, L., Secchioni, N., De Falcis, D., Maggiore, T., Stanca, A.M., 1998. Uptake and agronomic efficiency of nitrogen in winter barley and winter wheat. Eur. J. of Agron. 9: 11-20.

Dalla Costa, L., Giovanardi, R., 1996. Nitrogen use efficiency and nitrate losses in sunflower and maize: a comparison. Proceeding of the $14^{\text {th }}$ International Sunflower Conference, Peking, 284-289.

Hocking, P.J., Steer, B.T., 1995. Effects of timing and supply of nitrogen on nitrogen remobilization from vegetative organs and redistribution to developing seeds of sunflower. Plant and Soil 170: 359-370.

Janzen, H.H., Beauchemin, K.A., Bruinsma, Y., Campbell, C.A, Desjardins, R.L., Ellert, B.H., Smith, E.G., 2003. The fate of nitrogen in agroecosystems: an illustration using Canadian estimates. Nutrient Cycling in Agroecosystems 67: 85-102.

Leto, C., Montemurro, F., Losavio, N., Bottazzi, P., Giordano, I., Marras, G., Palazzo, D., Sunseri, F., 1997. Sunflower (Helianthus annuus L.) response to low input in different Mediterranean environments. Riv. di Agron. 31(4): 984-992.

Lòpez-Bellido, R.J., Lòpez-Bellido, L., Castillo, J.E., Lòpez-Bellido, F.J., 2003. Nitrogen uptake by sunflower as affected by tillage and soil residual nitrogen in a wheat-sunflower rotation under rainfed Mediterranean conditions. Soil \& Tillage Research 72: 43-51.

Magdoff, F., Lanyon, L., Liebhardt, B., 1997. Nutrient cycling, transformations, and flows: implications for a more sustainable agriculture. Adv. Agron. 60: 1-73.

Montemurro, F., Convertini, G., Maiorana, M., Ferri, D., 2002. N-use efficiency, yield and quality in maize-winter barley. Agrochimica 46(3-4): 146-154.

Murillo, J.M., Moreno, F., Pelegrín, F., Fernanández, J.E., 1998. Responses of sunflower to traditional and conservation tillage under rainfed conditions in southern Spain. Soil \& Tillage Research 49: 233-241.

Owen, D.F., 1983. Differential response of sunflower hybrids to planting data. Agron. J. 75: 259-262 
Sas Institute, 1990. SAS/STAT Software. SAS Institute Inc. Cary, NC.

Scheiner, J.D., Gutiérrez-Boem, F.H., Lavado, R.S., 2002. Sunflower nitrogen requirement and 15N fertilizer recovery in Western Pampas, Argentina. Eur. J. of Agron. 17: 73-79.

Sinsawat, V., Steer, B.T., 1993. Growth of florets of sunflower (Helianthus annuus L.) in relation to their position in the capitulum, shading and nitrogen supply. Field Crops Res. 34: 83-100.

Steer, B.T., Hocking, P.I., Low, A., 1985. Nitrogen nutrition of sunflower (Helianthus annuus L.): concentrations, partitioning between organs and redistribution of $\mathrm{N}$ in seven genotypes in response to N supply. Field Crops Res. 12: 17-32.

Thavaprakash, N., Siva Kumar, S.D., Raja, K., Senthil Kumar, G., 2002. Effect of nitrogen and phosphorus levels and ratios on seed yield and nutrient uptake of sunflower hybrid DHSI. Helia 37: 59-68.

Ujjanaiah, U.S., Thimmegowda, S., Sridhara, S., Prasad, T.G., 1995. Effect of moisture, plant population and fertilizer regimen on yield of sunflower. Helia 22: 77-82.

Zaffaroni, E., Schneiter, A.A., 1991. Sunflower production as influenced by plant type, plant population, and row arrangement. Agron. J. 83: 113-118.

\section{EXPERIMENTO DE CUATRO AÑOS DE DURACIÓN SOBRE LA APLICACIÓN DE NITROGENO EN LOS GENOTIPOS DE GIRASOL EN UNA ÁREA EN CONDICIONES SEMIARIDAS}

\section{RESUMEN}

Se ha llevado a cabo un experimento durante cuatro años para estudiar los efectos de diferentes cantidades de $\mathrm{N}$ en las cosechas, los componentes, la absorción de $\mathrm{N}$ y la calidad de las semillas de los genotipos del girasol cultivados en condiciones semiarias de la zona Mediterránea.

Cinco genotipos (cuatro híbridos comerciales y un genotipo nuevo selecionado) y tres niveles de fertilización con $\mathrm{N}\left(0,50\right.$ y $\left.100 \mathrm{~kg} \mathrm{~N}^{-1}\right)$ han sido comparados durante cuatro años (1966, 1997, 1998 y 1999).

Se han recogido las plantas en el tempo de floración y el peso en seco, el índice de superficie de la hoja y el contendo total de $\mathrm{N}$ han sido determinados; en cuanto e la fase de maduración, se han determinado la cosecha, los componentes, el contendo de aceite, el contendo de proteina, la absorción de $\mathrm{N}$ y la calidad de la semilla.

Los resultados indican una diferencia significativa en la actuación del cultivo (producción de semillas, aceite y proteinas) durante todos los años (de $2.52 \mathrm{t} \mathrm{ha}^{-1}$ en 1996 a $3.81 \mathrm{t} \mathrm{ha}^{-1}$ en 1999), lo que confirma la necesidad de seleccionar los genotipos recomendados y adaptar las percentuales de fertilizantes a las necesidades de las cosechas especialmente en ambiente Mediterráneo donde las condiciones atmosféricas son imprevedibles y variables. De hecho, los genotipos han mostrado diferente comportamiento durante todos estos años en la absorción total de $\mathrm{N}$, en la producción de semillas, aceite $\mathrm{y}$ proteinas, demostrando que la cosecha de girasol es susceptible de gestión agronómica.

El más alto nivel de fertilizante de $\mathrm{N}$ ha demostrado la major actuación del girasol aunque, debido a un cambio de años y genotipos, el fertilizante $\mathrm{N}$ podría ser aplicado sobre una base anual de acuerdo con la total absorción de $\mathrm{N}$. Por último, la absorción de $\mathrm{N}$ y el diámetro de la cabeza han sido los parámetros más importantes que han influenciado la actuación del cultivo del girasol. 


\title{
QUATRE ANNÉES D'EXPÉRIMENTATION SUR L'APPLICATION D'AZOTE SUR DES GÉNOTYPES DE TOURNESOL EN CONDITIONS SEMI ARIDE
}

\author{
RÉSUMÉ
}

L'objectif de l'expérimentation, menée en conditions de plein champ sur quatre années, était d'étudier l'effet de différentes doses d'azote sur le rendement et ces composantes, l'azote total absorbé et la qualité de graines des génotypes du tournesol cultivés en conditions semi aride.

Cinq génotypes (quatre hybrides commerciaux et un nouveau sélectionné) et trois niveaux de fertilisation azotée $\left(0,50\right.$ et $\left.100 \mathrm{~kg} \mathrm{~N} \mathrm{ha}^{-1}\right)$ ont été comparé durant quatre années (1996, 1997, 1998 et 1999).

Au stade floraison, sur des plantes prélevées, la matière sèche, indice de la superficie foliaire et le contenu total d'azote ont été déterminé. Alors que, au stade maturité, le rendement et ces composantes, contenu d'huile, contenu de protéine, azote total absorbé et qualité des graines ont été évalué

Les résultats obtenues ont indiqué une différence significative concernant la performance en rendement (production en graine, huile et protéine) au cours des années (de $2.52 \mathrm{t} \mathrm{ha}^{-1}$ en 1996 à $3.81 \mathrm{t} \mathrm{ha}^{-1}$ en 1999), confirmant la nécessité de sélectionner des génotypes recommandés et d'ajuster la dose de fertilisation selon les besoins de la plante, spécialement dans l'environnement Mediterranean où les conditions du temps sont imprévisibles et variables.

En réalité, les génotypes étudiés ont montré un comportement différent au cours des années en ce qui concerne l'azote total absorbé, la production en graine, huile et protéine, en indiquant que la plante du tournesol est susceptible à la gestion des techniques agronomiques. En outre, le niveau de fertilisation azotée plus élevé a montré aussi la meilleure performance du tournesol, bien que due aussi à la variation des années et des génotypes, la fertilisation azotée doit être appliquée sur la base annuelle, selon l'azote total absorbé. En fin, l'azote total absorbé et le diamètre des capitules sont les plus importants paramètres qui ont influencé la performance en rendement du tournesol. 